\title{
MSF: how a humanitarian charity found itself leading the world's response to Ebola
}

Médecins Sans Frontières was there at the start of the current Ebola outbreak in west Africa and has played a pivotal role in the global response-building health centres, training care staff, and even advising the United Nations, writes Sophie Arie. The charity has decades of experience in bringing volunteer doctors to where they are needed in emergency situations and for longer term humanitarian projects. This is why The BMJ has chosen MSF for its winter charity appeal this year. Please give generously

\section{Sophie Arie freelance journalist, London, UK}

Caring for patients who are sick, terrified, and sometimes delirious is hard enough. But working flat out in basic facilities and sweltering heat, while constantly aware that one small mistake could lead to care workers becoming infected themselves, makes treating patients with Ebola virus disease in west Africa one of the toughest humanitarian challenges of our time.

So imagine if amid that heat and pressure a care worker realises that a fly-known as an "acid bug" because if crushed it can burn and blister skin-has got inside her protective goggles. That's what happened to a nurse working in a high risk room at the Ebola case management centre in Bo, Sierra Leone, run by Médecins Sans Frontières (MSF or Doctors Without Borders). She panicked and was about to rip the goggles off to get the creature out, but a hygienist in the room shouted, "No! Close your eyes!" and led her out to remove her protective clothing safely and get rid of the bug without risking exposure to the Ebola virus.

\section{Expertise and commitment}

MSF's expertise in treating Ebola virus disease, combined with its commitment to working in places where others fear to go, means that it has emerged as the leader in the west African outbreak.

The charity had a team in Guinea when the outbreak began in March and has followed the virus as it has spread-building treatment centres in locations as disparate as the jungle and capital cities, deploying mobile units, providing technical support to governments, and training staff. Today MSF has more than 3400 staff on the ground (with one international staff member for every 10 local staff members) and says that it has cared for almost 4000 patients confirmed to have Ebola and many more suspected cases.
As the outbreak gained pace and caused alarm worldwide the international community ramped up its response. The charity was asked, for the first time, to advise the United Nations' security council as it assessed the threat to global health. MSF has increasingly found itself asked to take on roles that are "outside its comfort zone" because they divert its staff from their core work, MSF's international director, Joanne Liu, told The BMJ.

\section{Training others}

In August 2014 MSF began training others-in the military, government, and charities-who wanted to run treatment centres but lacked the knowhow. So far 150 people from 25 different organisations have gone through the same "hot and cold" training that the charity's own teams go through — a rigorous two day course in a simulation centre in Brussels followed by time working in an MSF treatment centre in west Africa.

MSF's staff do not work with full protective gear, which includes helmets with breathing apparatus and isolation beds, like the teams that have treated patients with Ebola in western countries. Instead its staff wear ordinary protective clothing (goggles, gloves, and layers of gowns) and keep safe by keeping calm, even when the unexpected happens (such as getting an acid bug inside their goggles). They follow meticulous procedures for dressing, undressing, and cleaning clothes and equipment. Hygiene workers spray everyone and everything with chlorine solution at each crucial stage.

Since the response began, 27 local MSF staff members have fallen ill with Ebola, 14 of whom have recovered and 13 of whom have died. The charity has found that most came into contact with the virus in the community rather than on the job. 
Only two international staff have been infected, both of whom recovered.

Clinical trials of three potential Ebola treatments are planned to begin imminently in MSF treatment centres throughout the region, again diverting resources from the main task of caring for patients. "We have been stretched more than ever before," said Liu. "It is unbelievable that the global response has depended so much on a private humanitarian organisation."

When the outbreak is finally under control, MSF plans to review its response and assess whether it could have done better. But without this feisty, competent, and fast moving medical charity the current epidemic, which the international community is still struggling to control, would undoubtedly have been much worse.
Competing interests: I have read and understood BMJ's policy on declaration of interests and have no relevant interests to declare.

Provenance and peer review: Commissioned; not externally peer reviewed.

thebmj.com Feature: Operation Gritrock: Christmas bulletin from UK army medics in Sierra Leone (BMJ 2014;349:g7721, doi:10.1136/bmj. g7721)

Access all of The BMJs content on the ongoing Ebola outbreak at thebmj.com/ebola.

Cite this as: $B M J$ 2014;349:97737

๑ BMJ Publishing Group Ltd 2014 
MSF's volunteer doctors need your support: please give generously

- £38 can pay for a suit to protect against Ebola virus

- $£ 53$ can send a doctor to the field for a day

- $£ 95$ can provide a year's supply of treatment for a person with HIV or AIDS

- £153 can provide lifesaving blood transfusions for three people

You can donate:

- Online at www.msf.org.uk/thebmj

- By phone: +44 (0)800 4083897

- £5 by texting "Doctor" to $70111^{*}$

*UK mobile networks only. You will be charged $£ 5$, plus your standard network rate. MSF will receive $100 \%$ of the $£ 5$ donation. If you have any questions please call $+44(0) 2074046600$. 